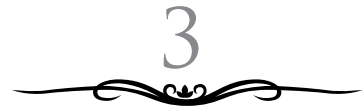

\title{
PELUANG DAN TANTANGAN PELAYANAN PERPUSTAKAAN BERBASIS MEDIA SOSIAL: Perspektif Pustakawan Stain Kudus
}

\author{
Nuskhan Abid \\ STAIN Kudus, Jawa Tengah, Indonesia \\ nuskhan@stainkudus.ac.id
}

\begin{abstract}
Social media and the internet isserious challenges for the library to maintain their consistency in the terms of the scientific dissemination. This article aimed to know the opportunities and challenges of social media-based library services from the librarian perspective. Observation and interviews are used to know the librarian opinion about the opportunities and challenges in the implementation of the social mediabased library services platform in STAIN Kudus, Central Java, Indonesia. STAIN Kudus library have the opportunity to implement social media-based services including information the collection of books, books lease extended time, expanding the network and communication between librarians and readers. Limited infrastructure, the limited number of librarians, the limited number of students who have the device to access the social media are the challenges faced by library. Strengthening the librarian resources, training, and the leader policy will open the opportunity to implement social media-based services.
\end{abstract}

Keywords:Opportunity; challenges; Social Media; Services; librarian. 


\begin{abstract}
Abstrak
Era media sosial dan kemajuan internet menjadi tantangan bagi setiap perpustakaan untuk tetap mempertahankan konsistensinyasebagaipelayannomorsatudalamhalpersebaran keilmuan. Artikel ini bertujuan untukmengetahui peluang dan tantangan pelayanan perpustakan berbasis media sosial dari perspektif pustakawan STAIN Kudus. Teknik observasi dan wawancara untuk mengetahui pendapatpustakawan tentang peluang dan tantangan penerapan media sosial sebagai alat bantu pelayanan di perpustakaan STAIN Kudus, Jawa Tengah Indonesia.Hasilnya adalah perpustakaan STAIN Kudus mempunyai peluang untuk menerapkan pelayanan berbasis media sosial yang diantaranya adalah:informasi koleksi buku, informasi perubahan waktu pelayanan, memperpanjang masa peminjaman buku, memperluas jaringan komunikasi antar pustakawan dan pemustaka. Sedangkan tantangan yang dihadapi diantaranya adalah: terbatasnya sarana dan prasarana, terbatasnya jumlah pustakawan, terbatasnya jumlah mahasiswa yang memiliki perangkat untuk mengakses media sosial. Penguatan sumber daya pustakawan, pelatihan dan kebijakan pimpinan akan dapat membuka peluang untuk menerapkan pelayanan berbasis media sosial di perpustakaan STAIN Kudus.
\end{abstract}

Kata Kunci: Peluang, Tantangan, Pelayanan, Media sosial, pustakawan.

\title{
A. Pendahuluan
}

Internet telah merubah cara manusia dalam proses pencarian data. Data yang dirilis oleh Asosiasi Penyelenggara Jasa Internet Indonesia (APJII) pada oktober 2016 menyebutkan bahwa 31,3 juta penduduk Indonesia mengakses internet untuk mendapatkan informasi dan 12,2 juta penduduk mengakses internet untuk kepentingan pendidikan. ${ }^{1}$ Internet juga mengubah

${ }^{1}$ Asosiasi Pengguna Jasa Internet Indonesia, "APJII - Statistik Oktober 2016," Asosiasi Pengguna Jasa Internet Indonesia, 9, diakses 18 Januari 2017, https://apjii.or.id/survei. 
cara manusia untuk berinteraksi satu dengan yang lainnya melalui media sosial. Media sosial memungkinkan manusia untuk berinteraksi dengan siapapun juga dibelahan bumi manapun dan tidak terbatas waktu. 97,4\% atau sekitar 129,2 juta jiwa penduduk Indonesia merupakan pengguna media sosial. ${ }^{2}$ Dengan jumlah yang sebesar itu tentu saja akan berdampak pada segala sektor. Salah satunya adalah perpustakaan. Hadirnya internet dan media sosial menjadi tantangan bagi perpustakaan untuk tetap eksis dalam upayanya menjadi lumbung utama untuk persebaran informasi dan ilmu pengetahuan.

Kemudahan-kemudahan yang ditawarkan oleh internet tentunya akan berdampak kepada menurunnya minat mengunjungi perpustakaan. Karena saat ini cukup dari telepon genggam semua orang akan mendapatkan informasi dengan sangat cepat. Seperti yang terjadi di Yogyakarta, bahwa masyarakat lebih memilih membaca dan mendapatkan informasi melalui internet daripada datang ke perpustakaan. ${ }^{3}$ Pengunjung merasa tidak perlu repot lagi untuk mencari ratusan koleksi buku di perpustakaan, sehingga mereka tidak merasa lelah dan terbuang waktunya. Pengelola perpustakaan harus mempunyai cara yang tepat untuk menarik pengunjung dan membuat pengunjung merasa lebih dekat dengan perpustakaan. Perpustakaan harus mampu beradaptasi dengan kemajuan teknologi. Tidak hanya mengupayakan penambahan koleksi buku-buku yang berkualitas tetapi juga mendorong pelayanan yang maksimal dan sesuai dengan perkembangan zaman. Adanya sistem informasi perpustakaan terkadang menjadi satu hal yang mubazir, karena tidak semua orang mengaksesnya dan familiar dengan hal ini. Dibutuhkan teknik dan metode baru yang lebih segar untuk menarik minat pengunjung untuk kembali ke perpustakaan.

\section{${ }^{2}$ Ibid., 15 .}

3 Uli Febriarni, "MINAT BACA: Perpustakaan Semakin Sepi Pengunjung -Jogjapolitan » Harian Jogja," Harian Jogja, diakses 2 Februari 2017, http://www.harianjogja.com/baca/2016/04/25/minat-baca-perpustakaansemakin-sepi-pengunjung-713516. 
Penelitian terdahulu yang dilakukan oleh Agosto dkk tentang mitos dan realitas antara media sosial dan perpustakaan di kalangan remaja, disebutkan bahwa remaja menggunakan media sosial sebagai alat komunikasi dinamis bukan sebagai sumber informasi statis. ${ }^{4}$ Kajian lain yang dilakukan oleh Anwar dalam Jurnal Khizanah Al Hikmah, menyatakan bahwa media sosial dapat digunakan untuk mendukung layanan referensi, mempromosikan kegiatan dan koleksi perpustakaan. ${ }^{5}$ Brookbank dalam penelitiannya tentang strategi penggunaan media sosial untuk perpustakaan dan tanggapan siswa terhadap pemilihan platform media sosial yang tepat untuk perpustakaan. ${ }^{6}$ Media sosial dapat dimanfaatkan untuk pelayanan perpanjangan masa peminjaman koleksi perpustakaan menggunakan Facebook. Penelitian yang dilakukan oleh Siswanti menyatakan bahwa layanan perpanjangan masa peminjaman koleksi melalui Facebook sangat bermanfaat. ${ }^{7}$ Tentu menjadi kebutuhan yang mendesak bagi setiap pengelola perpustakaan untuk terus berinovasi dalam hal pelayanan. Pelayanan berbasis media sosial dapat dijadikan alternatif bagi pengelola perpustakaan.

Selama ini pelayanan di perpustakaan STAIN Kudus mengharuskan pemustaka untuk datang langsung ke perpustakaan. Walaupun sudah ada sistem OPAC (Online Public Acces Catalog) tetapi sistem ini masih memiliki kelemahan, salah satunya adalah tidak adanya fasilitas perpanjangan masa peminjaman buku, tidak

${ }^{4}$ Denise E. Agosto et al., "Teens, Libraries, and Social Media: Myths and Reality.”, Public Library Quarterly 34, no. 4 (2 Oktober 2015): 325, doi:10.1 080/01616846.2015.1106892.

5 Ahmad Anwar, "Pemanfaatan Media Sosial Dalam Pelayanan Referensi 2.0 di Indonesia," Khizanah AlHikmah 4, no. 1 (2016):, hlm. 63.

${ }^{6}$ Elizabeth Brookbank, "So Much Social Media, So Little Time: Using Student Feedback to Guide Academic Library Social Media Strategy," Journal of Electronic Resources Librarianship 27, no. 4 (2 Oktober 2015): 242, doi:10.10 80/1941126X.2015.1092344.

7 Apriani Siswanti, "Pemanfaatan Layanan Perpanjangan Masa Peminjaman Koleksi Melalui Media Sosial Facebook di Perpustakaan Fakultas Ilmu Sosial dan Ilmu Politik Universitas Gadjah Mada Yogyakarta," Berkala Ilmu Perpustakaan dan Informasi 11, no. 2 (2015), hlm. 7. 
adanya fasilitas real chat (komunikasi secara langsung) dengan pustakawan. Hal inilah yang membuat kondisi perpustakaan begitu padat dan tidak kondusif, karena banyaknya jumlah mahasiswa yang mengantri untuk mendapatkan pelayanan dari pustakawan. Kebijakan untuk merubah model pelayanan yang konvensional menjadi pelayanan berbasis daring belum berjalan.

Artikel ini berupaya untuk mengetahui bagaimana tanggapanpustakawan STAIN Kudus tentang peluang dan tantangan dalam pemanfaatan sosial media sebagai bagian dari proses pelayanan. Apa saja bentuk-bentuk pelayanan berbasis media sosial yang dapat dilakukan di perpustakaan STAIN Kudus? Apa saja kendala-kendala yang dihadapi oleh pustakwan STAIN Kudus dalam menerapkan pelayanan berbasis media sosial? Artikel ini sangat penting untuk perkembangan dunia kepustakaan karena diharapkan akan lahir kebijakan-kebijakan yang inovatif, konstruktif, dan kekinian untuk kemajuan perpustakaan di masa yang akan datang. Selain itu kebijakan penggunaan sosial media dalam pelayanan perpustakaan diharapkan dapat merubah citra perpustakaan yang konvensional menjadi lebih modern dan dekat dengan masyarakat.

\section{B. Pembahasan}

Ada beberapa hal yang perlu dikaji dalam artikel ini terkait dengan peluang dan tantangan penggunaan media sosial sebagai wahana pelayanan transaksi di perpustakaan. Sebelum kita melangkah lebih jauh, ada baiknya untuk melihat bagaimana bentuk pelayanan di perpustakaan.

\section{Bentuk Pelayanan Perpustakaan}

Perpustakaan tidak hanya identik dengan koleksi buku. Ada elemen lain yang juga mempunyai peranan yang tidak dapat tergantikan, yaitu pelayanan. Pelayanan di perpustakaan selalu berupaya untuk mendayagunakan seluruh koleksinya agar dapat dimanfaatkan secara optimal oleh pengunjung. ${ }^{8}$ Pelayanan

8 Andi Prastowo, Manajemen Perpustakaan Sekolah Profesional (Yogyakarta: DIVA Press, 2012), hlm. 224. 
di perpustakaan tidak hanya terbatas pada proses transaksi peminjaman atau pengembalian buku saja, tetapi ada banyak hal yang dapat dikategorikan sebagai bentuk pelayanan.Karena pentingnya pelayanan ini,Elvina ${ }^{9}$ dalam penelitiannya menyatakan bahwa pelayanan informasi di perpustakaan dapat dijadikan komoditas bisnis yang berdaya nilai jual tinggi.Selain itu, optimalisasi pelayanan dan strategi yang kreatif sangat dibutuhkan pustakawan untuk menarik minat masyarakat mengunjungi perpustakaan. ${ }^{10}$ Selain dua hal di atas, pelayanan pada saat ini pelayanan juga dapat dilakukan melalui media short message service (SMS) seperti penelitian yang dilakukan oleh Anbu dan Jety di dua kampus yang berbeda. ${ }^{11}$

Prastowo menyebutkan tiga macam kegiatan yang ada di sebuah perpustakaan diantaranya adalah; penghimpunan, kegiatan pengolahan, dan kegiatan penyebarluasan informasi. ${ }^{12}$ Kegiatan pelayanan di sebuah perpustakaan merupakan salah satu kegiatan penyebarluasan informasi. Karena dalam tahap inilah pustakawan melakukan tugas untuk melayani pengunjung dalam hal peminjaman buku koleksi perpustakaan. Lebih lanjut, Prastowo juga menjelaskan bahwa kegiatan penyebarluasan informasi diantaranya pelayanan promosi, pelayanan referensi dan informasi, pelayanan peminjaman koleksi, pelayanan bimbingan kepada pembaca. Termasuk dalam hal ini adalah pelayanan kepada

${ }^{9}$ Irma Elvina, "Membisniskan Layanan Perpustakaan Menggunakan E-Commerce," Jurnal Pustakawan Indonesia 10, no. 2 (2013), hlm. 24.

10 Muhammad Miftah, "Optimalisasi Kinerja Pustakawan Dalam Meningkatkan Visitasi Pemustaka," Libraria: Jurnal Perpustakaan 4, no. 2 (2016), hlm. 316.

${ }^{11}$ K. John Paul Anbu dan Sridevi Jetty, "Use of Short Message Service (SMS) to Maximize the Library Usage: A Tale of Two Libraries," in Digital Libraries: Social Media and Community Networks, ed. oleh Shalini R. Urs, Jin-Cheon $\mathrm{Na}$, dan George Buchanan (Springer International Publishing Switzerland, 2013), 143, doi:10.1007/978-3-319-03599-4.

12 Prastowo, Manajemen Perpustakaan Sekolah Profesional, hlm. 59- 60 . 
siswa dan guru dalam rangka mencari informasi yang berkaitan dengan minat mereka. ${ }^{13}$

Pelayanan tidak hanya berkaitan dengan proses peminjaman koleksi, tetapi lebih jauh seorang pustakawan juga harus mampu menyediakan hal-hal lain diluar transaksi koleksi-koleksi buku. Kita bisa melihat kasus di Cina, dimana perpustakaan tidak hanya menyediakan koleksi-koleksi buku, tetapi sudah menjadi pusat informasi untuk sains, kesehatan, teknologi informasi, dan pertanian sejak Kementerian Pendidikan China menginisiasi China Academic Library and Information System (CALIS) di tahun $1998 .{ }^{14}$ Inilah tugas utama perpustakaan, terutama elemen yang ada di dalamnya untuk menyediakan layanan yang tidak hanya terfokus pada transaksi dan perputaran koleksi saja. Dengan perkembangan teknologi dan informasi, saat ini pustakawan tidak hanya sebagai penjaga buku semata. Pustakawan harus mampu menyajikan informasi dan lebih aktif dalam hal pencarian informasi bagi pengunjung. ${ }^{15}$

Perpustakaan adalah jantung dari perkembangan ilmu pengetahuan. Didalamnya terdapatinformasitanpabatasyang dapat digunakan untuk kepentingan umat manusia. Setiap perpustakaan tentunya mempunyai sistem dan tata kelola yang berbeda-beda. Strategi dan pendekatan yang digunakan setiap perpustakaan dalam proses pengelolaan dan pelayanan menentukan keberlangsungan proses transaksi di perpustakaan. Hari ini manusia diberikan kemudahan dalam hal akses informasi di internet. Informasi tersaji tanpa batas dan tak ada sekat yang menghalangi siapapun juga yang mengaksesnya melalui media internet. Tantangan yang sangat besar bagi pengelola perpustakaan untuk dapat menyajikan pelayanan terbaik bagi setiap pengunjungnya. Dengan kemudahan akses yang ditawarkan oleh internet, tentunya setiap

${ }^{13}$ Prastowo, Manajemen Perpustakaan Sekolah Profesional, hlm, 60.

${ }^{14}$ Yalan Yan et al., "Comparing digital libraries with virtual communities from the perspective of e-quality," Library Hi Tech 32, no. 1 (2014): 174, doi:10.1108/LHT-04-2013-0042.

${ }^{15}$ Prastowo, Manajemen Perpustakaan Sekolah Profesional, hlm, 78. 
orang akan memilih untuk mendapatkan referensi di internet dibandingkan dengan datang ke perpustakaan secara langsung. Akses-akses informasi yang cepat dan mudah di internet tentu saja mempengaruhi jumlah kunjungan ke perpustakaan.

Perkembangan Teknologi Informasi dan Komunikasi (TIK) membuat perpustakaan mampu menyediakan akses ke segala hal dan menjembatani kesenjangan antara pengetahuan lokal dan global. ${ }^{16}$ Pelayanan berbasis internet seperti pencarian secara online, pelayanan berbasis e-mail, dan pelayanan referensi online harus disediakan oleh perpustakaan, termasuk pemberian pelayanan untuk akses informasi yang berbeda sehingga pelayanan tidak hanya terbatas pada pelayanan sirkulasi semata. ${ }^{17}$ Beberapa inovasi terkait dengan pelayanan perpustakaan sebaiknya perlu untuk dilakukan perubahan dalam berbagai aspek. Memang hal ini berkaitan dengan fasilitas serta sarana dan prasarana yang dimiliki oleh setiap perpustakaan. Tetapi, pelayanan referensi online, ataupun persebaran informasi hanya memerlukan jaringan internet. Dibutuhkan tenaga perpustakaan yang mampu menggunakan perangkat-perangkat tersebut sehingga dapat dimanfaatkan untuk pelayanan yang lebih global.

Coba kita lihat pelayanan yang dilakukan oleh Vancouver Public Library (VPL) di Kanada, selama tahun 2011 mereka telah menjawab lebih dari 900.000 pertanyaan tentang referensi dan sumber kepustakaan. ${ }^{18}$ Sejak kekuatan internet menyerbu kolong jagat, kemudahan berkomunikasi dan kecepatan akses terhadap informasi seharusnya dapat dimanfaatkan kalangan pustakawan

${ }^{16}$ R S R Varalakskhmi, "Future of Library and Information Centres in Knowledge Society of India : The Expected Role of Knowledge Professionals," Journal of Library and Information Technology 29, no. 2 (2009), hlm, 76.

${ }^{17}$ Justina N Ekere dan Charles O. Omekwu, "Users' Perception of the Facilities , Resources and Services of the MTN Digital Library At the University of Nigeria , NSUKKA," no. April (2016).

${ }^{18}$ Kay Cahill, "The Library in the Social Network: Twitter at the Vancouver Public Library," in Using Social Media in Libraries: Best Practices, ed. oleh Charles Harmon dan Michael Messina (Plymouth: Scarecrow Press, Inc., 2013), hlm, 66. 
di Indonesia.Perubahan paradigma pelayanan dari konvensional menuju sesuatu yang baru memang menjadi tantangan yang harus dihadapai oleh setiap pustakawan di Indonesia.

\section{Perpustakaan dan Media Sosial}

Penggunaan media sosial, open-access journal, dan media daring memungkinkan kita semua mendapatkan informasi yang tidak terbatas. Media sosial seperti Facebook, Instagram, Twitter dapat digunakan untuk alternatif pelayanan perpustakaan. Selama ini media sosial digunakan untuk berkomunikasi dan membangun jejaring dengan setiap orang di segala penjuru dunia. Hagman dan Carleton menyatakan bahwa perpustakaan akademik banyak yang menggunakan media sosial agar dapat terhubung dengan komunitas kampus, mempromosikan pelayanan dan koleksi perpustakaan, serta untuk mendapatkan umpan balik dari pengunjung perpustakaan. ${ }^{19}$ Karena sifatnya yang sangat cepat, penggunaan media sosial dalam pelayanan dapat menghadirkan situasi yang real time. Ketika pelanggan memberikan komentar terkait pelayanan akan dengan cepat untuk ditindaklanjuti oleh para pustakawan. Jaringan yang luas memungkinkan pustakawan berbagi tentang koleksi pustaka mereka kepada setiap orang yang terhubung dengan media sosial. Hal ini tentu saja akan mempermudah pustakawan untuk mempromosikan programprogram pelayanan perpustakaan. Haryanto menyebutkan bahwa media sosial juga dapat digunakan untuk berkomunikasi dan membangun komunitas pustakawan dari program studi yang sejenis (homogen). ${ }^{20}$

Penggunaan media sosial dikalangan pustakawan seharusnya menjadi hal yang wajib sebagai bentuk pelayanan

${ }^{19}$ Jessica Hagman dan Janet Carleton, "Better Together: Collaborating with Students on Library Social Media.,” Public Services Quarterly 10, no. 3 (2014): 238, doi:10.1080/15228959.2014.931207.

${ }^{20}$ Haryanto, "Pemanfaatan Social Media Networks Sebagai Media Komunikasi Komunitas Pustakawan Homogen Dalam Rangka Optimalisasi Resources Sharing Knowledge Antar Perguruan Tinggi," Pustakaloka 8, no. 1 (2016), hlm, 121. 
terhadap pelanggan perpustakaan. Penggunaan media sosial pada saat jam kerja memang menimbulkan resiko yang cukup besar. Bisa dibayangkan, apabila seseorang menggunakan media sosial mereka ketika bekerja, maka dapat dipastikan bahwa fokus mereka akan terbagi. Dibutuhkan kebijakan dan aturan yang berbeda mengenai penggunaan media sosial pada saat jam kerja di lingkungan perpustakaan. Seperti yang ada di University of Liverpool yang mengharuskan staff mereka mempunyai media sosial untuk berinteraksi. ${ }^{21} \mathrm{Hal}$ ini tidaklah berlebihan, karena menurut Webb dan Laing penggunaan media sosial untuk perpustakaan dapat meningkatkan followers (pengikut) akun media sosial perpustakaan. Selain itu media sosial dapat mensosialisasikan acara dan program perpustakaan kepada setiap orang. Yang lebih utama adalah mendapatkan dukungan dari komunitas pustakawan. ${ }^{22}$ Pustakawan harus menyediakan tautan yang langsung terhubung dengan media sosial perpustakaan untuk dijadikan strategi promosi. ${ }^{23}$ Dengan sosial media pustakawan dapat mempromosikan programprogram perpustakaan kepada anak-anak muda. ${ }^{24}$ Oleh karena itu dorongan untuk melakukan pelayanan menggunakan media sosial harus terus didengungkan dan dicoba di lingkungan Perpustakaan STAIN Kudus, sebagai bagian dari inovasi dan perubahan, seperti penerapan pelayanan berbasis media sosial dan pemanfaatan sistem informasi perpustakaan yang optimal.

${ }^{21}$ Zelda Chatten dan Sarah Roughley, "Developing Social Media to Engage and Connect at the University of Liverpool Library," New Review of Academic Librarianship 22, no. 2-3 (2 Juli 2016): 251, doi:10.1080/13614533. 2016.1152985.

${ }^{22}$ Hillary Webb dan Ken Laing, "Engaging with Social Media: The Emily Carr University of Art and Design Library Experience.", Art Documentation: Bulletin of the Art Libraries Society of North America 34, no. 1 (2015): 140, doi:10.1086/680570.

${ }^{23}$ Webb dan Laing, "Engaging with Social Media: The Emily Carr University of Art and Design Library Experience.,", hlm, 140.

${ }^{24}$ Abigail L. Phillips, "Facebooking It: Promoting Library Services to Young Adults through Social Media," Public Library Quarterly 34, no. 2 (3 April 2015): 178, doi:10.1080/01616846.2015.1036710. 


\section{Metode Penelitian}

Penelitian ini menggunakanteknik observasi dan wawancara untuk mengetahui pendapatpustakawan tentang peluang dan tantangan penerapan media sosial sebagai alat bantu pelayanan di perpustakaan STAIN Kudus, Jawa Tengah Indonesia. Wawancara dilakukan dengan 9 orang pustakawan yang berkaitan dengan media sosial dan pelayanan perpustakaan. Kenapa harus pustakawan STAIN Kudus? Karena merekalah pelaku utama dalam hal proses pelayanan di perpustakaan. Selain itu wawancara juga dilakukan dengan Pimpinan Perpustakaan STAIN Kudus,karena pimpinan perpustakaan mempunyai kewenangan dalam hal penentuan kebijakan di masa yang akan datang mengenai penggunaan media sosial sebagai alat pelayanan di perpustakaan STAIN Kudus. Dari hasil wawancara, observasi dan dokumentasi yang terkumpul kemudian dianalisa untuk mendapatkan gambaran mengenai peluang dan tantangan penerapan media sosial untuk pelayanan perpustakaan di STAIN Kudus.

\section{Penggunaan Media Sosial Dikalangan Pustakawan STAIN Kudus}

Gambaran mengenai penggunaan media sosial dikalangan pustakawan STAIN Kudus akan dijelaskan dalam poin ini. Mayoritas pustawakawan STAIN Kudus mempunyai sosial media. Ada beberapa pertanyaan yang diajukan diantaranya adalah: Pertama, apakah pustakawan mempunyai media sosial? Kedua, jenis media sosial apakah yang dimiliki oleh pustakawan? Ketiga,pertanyaan yang terkait dengan fungsi dari media sosial bagi pustakawan. Keempat, penggunaan media sosial untuk kepentingan yang berkaitan dengan perpustakaan.Dari 9 orang pustakawan yang mengisi $100 \%$ atau sembilan orang semuanya mempunyai akun media sosial. Dari data ini dapat dikatakan bahwa pustakawan STAIN Kudus mengikuti perkembangan zaman, sehingga nantinya dapat diaplikasikan pada pelayanan perpustakaan STAIN Kudus di masa yang akan datang. 
Seluruh pustakawan STAIN Kudus bahkan memasang aplikasi khusus media sosial di ponsel mereka. Dari hasil questionnaire yang disebar diketahui bahwa pustakawan STAIN Kudus mempunyai media sosial untuk bersilaturrahim, update informasi dan terhubung dengan jejaring di luar. Facebook merupakan salah satu jenis media sosial yang paling banyak dimiliki oleh pustakawan di STAIN Kudus. Facebook menjadi media sosial yang paling populer dibandingkan dengan Instagram, Twitter ataupun Google+ (Gambar 1).Sembilan orang pustakawan yang ada di perpustakaan STAIN Kudus mempunyai facebook. Ada satu orang yang mempunyai facebook, twitter maupun instagram.

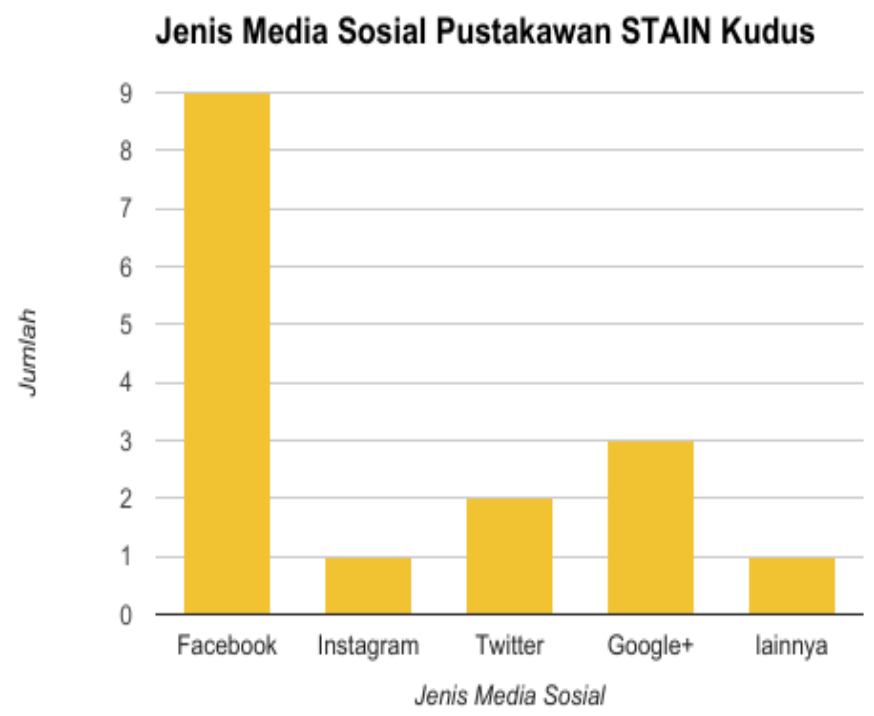

Gambar 1: Jenis media sosial Pustakawan STAIN Kudus

Pustakawan STAIN Kudus lebih sering menggunakan media sosial untuk beberapa aktifitas yang berhubungan dengan pembaruan status, mengirimkan foto, memberikan respon suka (like), membalas komentar dan mengirimkan pesan. Mengirim pesan merupakan aktifitas di media sosial yang paling banyak dilakukan oleh pustakawan STAIN Kudus, tujuh orang selalu 
melakukan aktifitas ini. Sebanyak empat orang mengirimkan/ membalas komentar. Aktifitas lainnya dapat dilihat pada grafik di bawah ini:

\section{Aktifitas Pustakawan di Media Sosial}

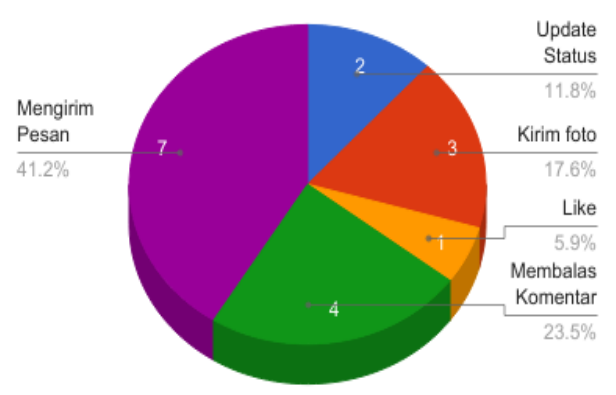

Gambar 2: Aktifitas Pustakawan STAIN Kudus di Media Sosial

Aktifitas yang dilakukan oleh pustakawan STAIN Kudus menunjukkan bahwa mereka tidak canggung dengan teknologi media sosial. Mereka terbiasa menggunakan media sosial berdasarkan hasil questionnaire yang disebarkan. Ketika mereka terbiasa melakukan pembaruan status (update status), mengirimkan pesan ataupun membalas komentar, hal tersebut merupakan peluang yang besar untuk memulai pelayanan perpustakaan dengan bantuan media sosial.

Aktifitas pustakawan STAIN Kudus di media sosial hanya sebatas aktifitas pribadi mereka dalam bermedia sosial, mereka belum memanfaatkan jejaring media sosial untuk menyebarluaskan informasi seputar perpustakaan. Hal ini dapat dilihat dari hasil questionnaire yang disebarkan, dari sembilan pustakawan hanya tiga orang yang mempromosikan kegiatan di perpustakaan, sebanyak enam orang tidak pernah sekalipun mempromosikan hal-hal seputar perpustakaan di media sosial mereka (Gambar 3). 


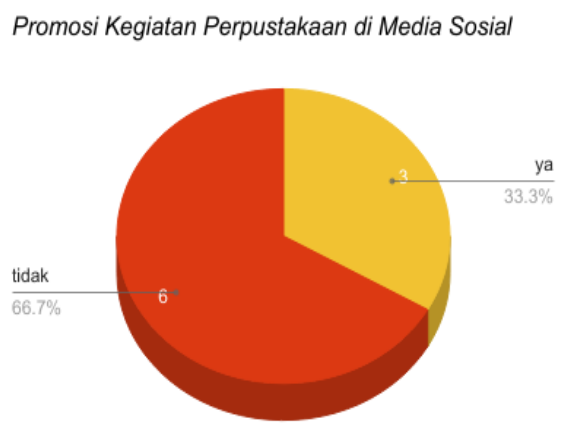

Gambar 3: Aktifitas pustakawan dalam mempromosikan kegiatan perpustakaan

Questionnaire yang disebarkan di dalamnya juga terdapat pertanyaan tentang kemungkinan penerapan pelayanan perpustakaan menggunakan media sosial. Mayoritas pustakawan STAIN Kudus setuju untuk menerapkan pelayanan denga bantuan media sosial (Gambar 4). Tujuh orang pustakawan menyatakan setuju dan sisanya 2 orang menyatakan tidak. Dari data di atas dapat dikatakan bahwa, pustakawan STAIN Kudus mempunyai semangat untuk merubah tradisi pelayanan dari konvensional ke pelayanan yang modern merupakan hal positif, mengingat inovasi dalam hal pelayanan merupakan salah satu cara untuk semakin dekat dengan pemustaka.

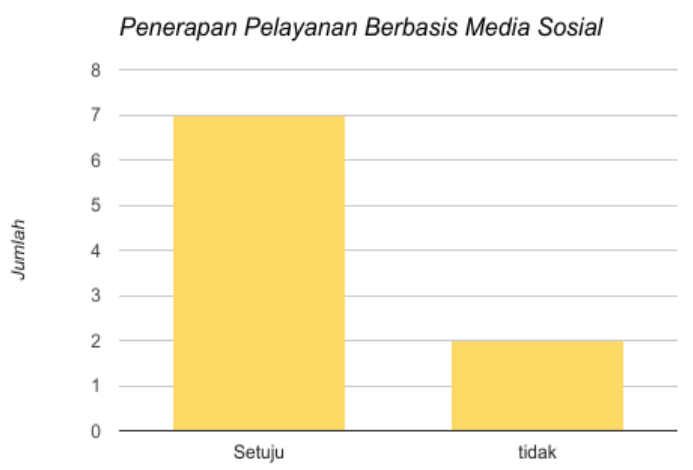

Gambar 4: Kemungkinan penerapan pelayanan berbasis Media Sosial 
Perpustakaan STAIN Kudus sudah mempunyai modal awal untuk menerapkan pelayanan perpustakaan berbasis media sosial berdasarkan hasil questionnaire yang sudah dipaparkan di atas. Selanjutnya menarik untuk dikaji bagaimana peluang dan tantangan pelaksanaan pelayanan perpustakaan menurut berbasis media sosial menurut putakawan STAIN Kudus.

\section{Peluang dan Tantangan Penerapan Pelayanan Menggunakan Media Sosial di Perpustakaan STAIN Kudus}

Wawancara yang dilakukan dengan pustakawan di perpustakaan STAIN Kudus menunjukkan bahwa mayoritas pustakawan mempunyai media sosial untuk berinteraksi dengan jejaring dan mendapatkan informasi. Penggunaan media sosial di kalangan pustakawan STAIN Kudus memungkinkan untuk melakukan pelayanan berbasis media sosial. Semua pustakawan sangat fasih ketika menggunakan media sosial sesuai dengan kebutuhan mereka. Adapun beberapa jenis pelayanan yang dapat dilakukan di perpustakaan STAIN Kudus menurut para pustakawan diantaranya;

Pertama, Informasi koleksi buku terbaru. Selama ini pustakawan tidak pernah melakukan promosi kepada para pemustaka mengenai penambahan koleksi buku yang terbaru. Dengan bantuan media sosial akan terbuka peluang bagipustakawan untuk mempromosikan koleksi buku-buku perpustakaan yang baru. Dengan mempromosikan koleksi buku-buku yang terbaru diharapkan pemustaka dapat memperoleh informasi yang terkini tentang kondisi perpustakaan. Setiap pemustaka di perpustakaan STAIN Kudus dapat melakukan pelayanan ini, karena mereka mampu untuk melakukan update status dan mengirimkan foto pada akun media sosial mereka. Dua aktifitas ini dibutuhkan untuk menampilkan gambar koleksi buku-buku yang terbaru serta memberikan komentar atau deskripsi tentang buku tersebut di dalam pembaruan yang dikirimkan melalui akun media sosial yang dimiliki perpustakaan. Selain koleksi buku-buku terbaru, perpustakaan juga dapat menginformasikan dan mempromosikan kepada pemustaka tentang daftar koleksi buku-buku yang tidak 
pernah dipinjam. Pustakawan juga dapat membuat postingan tentang buku yang paling banyak dipinjam, sehingga pemustaka lebih tertarik untuk datang ke perpustakaan.

Kedua, memberikan informasi jam pelayanan perpustakaan. Seringkali perpustakaan meliburkan pelayanan dikarenakan ada kegiatan, rapat, ataupun hal-hal yang mendesak. Pemustaka kerap tidak mendapatkan informasi perihal liburnya pelayanan perpustakaan. Media sosial menjadi salah satu alternatif untuk mengabarkan informasi pelayanan di perpustakaan. Pustakawan dapat memberikan pengumuman melalui akun media sosial perpustakaan, sehingga semua pemustaka yang terhubung akan mengetahui informasi tersebut. Selain informasi waktu pelayanan, media sosial juga dapat digunakan untuk mempromosikan kegiatan-kegiatan yang dilakukan oleh Perpustakaan. Seminar, workshop, bedah buku atau kegiatan yang berhubungan dengan perpustakaan dapat disebarluaskan melalui akun media sosial. Apalagi adanya fasilitas live status (semacam siaran langsung di televisi) pada media sosial memungkinkan perpustakaan untuk berbagi kegiatan yang sedang berlangsung kepada setiap pengikutnya secara langsung.

Ketiga, perpanjangan masa peminjaman buku. Perpustakaan STAIN Kudus membuka pelayanan mulai dari pukul 08.00 sampai dengan 16.00 setiap harinya. Pelayanan yang dilakukan diantaranya adalah perpanjangan masa pinjaman buku. Selama ini pelayanan perpanjangan masa peminjaman masih harus dilakukan secara langsung di perpustakaan. Media sosial dapat digunakan untuk melakukan transaksi masa peminjaman buku. Mahasiswa yang sudah terhubung dengan media sosial perpustakaan dapat mengirimkan pesan ataupun menulis di dinding akun media sosial perpustakaan mengenai permohonan perpanjangan masa peminjaman buku tanpa harus datang secara langsung ke Perpustakaan.Pustakawan hanya perlu melakukan cek pada sistem informasi perpustakaan untuk melakukan perpanjangan masa peminjaman buku bagi pemustaka. Apabila hal ini dilakukan akan 
menjadi satu terobosan yang baru dalam pelayanan perpustakaan di STAIN Kudus.

Keempat, kotaksaran. Tanyajawabantarapustakawandengan pemustaka yang berkaitan dengan perpustakaan. Pemustaka dapat menanyakan hal-hal yang berkaitan dengan koleksi buku, buku yang dipinjam, ketersediaan buku dan lain sebagainya. Pemustaka tidak perlu datang secara langsung ke perpustakaan hanya untuk melakukan tinjauan tentang ketersediaan buku. Selain itu adanya media sosial dapat dijadikan alat untuk bertukar saran dan gagasan. Kritik dan saran yang berkaitan dengan perpustakaan secara cepat akan dilihat dan ditindaklanjuti oleh pustakawan. Bandingkan dengan isian di kotak saran yang terkadang mahasiswa takut untuk mengisinya karena berbagai macam alasan, serta harus menunggu berbulan-bulan untuk dibuka petugas. Sifat media sosial yang real time menjadikannya sebagai perangkat pelayanan komunikasi yang sangat cepat.

Pelayanan perpustakaan menggunakan bantuan mediasosial di STAIN Kudus tidak selalu seperti yang diharapkan. Dari hasil wawancara, dapat diketahui bahwa ada beberapa tantangan dan keterbatasan untuk mewujudkan pelayanan perpustakaan berbasis media sosial. Adapun tantangan yang dihadapi perpustakaan STAIN Kudus untuk melaksanakan pelayanan berbasis media sosial diantaranya adalah:

Pertama, terbatasnya sarana dan prasarana. Sarana dan prasarana yang dimaksudkan adalah perangkat-perangkat yang mampu mendukung program pelayanan berbasis teknologi dan media sosial. Masalah yang paling banyak dikeluhkan oleh pustakawan adalah terbatasnya sarana dan prasarana. Hanya ada beberapa komputer saja yang digunakan untuk pelayanan sirkulasi. Kendala lainnya adalah terbatasnya jumlah kuota bandwitch, karena terkadang terjadi gangguan pada jaringan internet sehingga tidak dapat terkoneksi ke media sosial. Padahal prasyarat utama untuk dapat melaksanakan pelayanan berbasis media sosial adalah tersambung dengan jaringan internet. 
Kedua, jumlah pustakawan yang masih terbatas. Perpustakaan STAIN Kudus hanya memiliki enam belas orang pustakawan. Ada sekitar 10000 orang jumlah mahasiswa STAIN Kudus, hal ini membuat rasio pustakawan dengan pemustaka tidak seimbang.Dibutuhkan staff khusus yang harus melakukan pelayanan berbasis media sosial, karena selama ini pustakawan banyak melakukan pelayanan sirkulasi secara manual.Dengan menambah jumlah staff perpustakaan akan menambah optimal pelayanan. Tidak hanya pelayanan sirkulasi saja, tetapi pelayanan dalam bentuk yang lainnya semisal promosi dan sosialisasi tentang perpustakaan. Bertambahnya jumlah staff akan menjadikan pelayanan perpustakaan berbasis media sosial dapat dilaksanakan secara maksimal.

Ketiga, tidak semua mahasiswa mempunyai perangkat untuk mengakses media sosial, ponsel pintar dan paket data internet. Pustakawan menyebutkan bahwa hal inilah yang menjadi kendala utama diterapkannya pelayanan perpustakaan berbasis media sosial. Kendala jaringan internet yang kurang maksimal akan membuat akses ke media sosial perpustakaan menjadi terhambat. Optimalisasi jaringan internet nirkabelakan menjadikan akses ke internet menjadi lebih mudah. Hal lainnya yang menjadi kendala adalah tidak tersediannya perangkat seperti laptop, ataupun ponsel pintar untuk mengakses media sosial.

Keempat, perpustakaan STAIN Kudus belum memiliki akun media sosial. Kendala ini merupakan masalah utama kenapa pelayanan berbasis media sosial belum diterapkan di perpustakaan STAIN Kudus. Akun media sosial merupakan persyaratan utama untuk melaksanakan pelayanan berbasis media sosial. Selama ini perpustakaan STAIN Kudus belum mempunyai akun official (resmi) perpustakaan. Sehingga penerapan pelayanan promosi kegiatan, sosialisasi koleksi buku atau program-program perpanjangan waktu peminjaman belum dapat dilakukan. Selama ini sosialisasi kegiatan perpustakaan hanya dilakukan oleh pustakawan melalui akun media sosial pribadi, bukan akun media sosial resmi milik perpustakaan STAIN Kudus. 


\section{Simpulan}

Perpustakaan STAIN Kudus mempunyai potensi yang sangat besar untuk terus maju dan mengembangkan pelayanan berbasis media sosial. Perpustakaan STAIN Kudus dapat mengembangkan dan mengelola akun media sosial mereka untuk keperluan pelayanan seperti pengumuman, persebaran informasi koleksi baru, perubahan waktu pelayanan, ataupun promosi kegiatan-kegiatan yang berkaitan dengan perpustakaan. Pelayanan berbasis media sosial yang dapat dikembangkan di perpustakaan STAIN Kudus diantaranya adalah; informasi koleksi buku, informasi waktu pelayanan perpustakaan, perpanjangan masa peminjaman buku, dan kotak saran. Sedangkan tantangan yang dihadapi oleh pustakawan STAIN Kudus untuk menerapkan pelayanan berbasis media sosial diantaranya adalah; terbatasnya sarana dan prasarana, terbatasnya jumlah pustakawan, tidak semua mahasiswa memiliki perangkat untuk mengakses media sosial, dan yang terakhir adalah belum adanya media sosial khusus yang dimiliki oleh perpustakaan. 


\section{DAFTAR PUSTAKA}

Agosto, Denise E., Michelle Purcell, Rachel M. Magee, dan Andrea Forte. "Teens, Libraries, and Social Media: Myths and Reality." Public Library Quarterly 34, no. 4 (2 Oktober 2015): 318-27. doi:10.1080/01616846.2015.1106892.

Anbu, K. John Paul, dan Sridevi Jetty. "Use of Short Message Service (SMS) to Maximize the Library Usage: A Tale of Two Libraries." In Digital Libraries: Social Media and Community Networks, diedit oleh Shalini R. Urs, Jin-Cheon $\mathrm{Na}$, dan George Buchanan, 143-46. Springer International Publishing Switzerland, 2013. doi:10.1007/978-3-31903599-4.

Anwar, Ahmad. "Pemanfaatan Media Sosial Dalam Pelayanan Referensi 2.0 di Indonesia." Khizanah AlHikmah 4, no. 1 (2016).

Brookbank, Elizabeth. "So Much Social Media, So Little Time: Using Student Feedback to Guide Academic Library Social Media Strategy." Journal of Electronic Resources Librarianship 27, no. 4 (2 Oktober 2015): .doi:10.1080/1941126X.2015.1092 344.

Cahill, Kay. "The Library in the Social Network: Twitter at the Vancouver Public Library." In Using Social Media in Libraries: Best Practices, diedit oleh Charles Harmon dan Michael Messina, 114. Plymouth: Scarecrow Press, Inc., 2013.

Chatten, Zelda, dan Sarah Roughley. "Developing Social Media to Engage and Connect at the University of Liverpool Library." New Review of Academic Librarianship 22, no. 2-3 (2 Juli 2016): 249-56. doi:10.1080/13614533.2016.1152985.

Ekere, Justina N, dan Charles O. Omekwu. "Users ' Perception of the Facilities, Resources and Services of the MTN Digital Library At the University of Nigeria , NSUKKA," no. April (2016). 
Elvina, Irma. "Membisniskan Layanan Perpustakaan Menggunakan E-Commerce." Jurnal Pustakawan Indonesia 10, No. 2 (2013).

Febriarni, Uli. "MINAT BACA: Perpustakaan Semakin Sepi Pengunjung -Jogjapolitan» Harian Jogja." Harian Jogja. Diakses 2 Februari 2017. http://www.harianjogja.com/ baca/2016/04/25/minat-baca-perpustakaan-semakinsepi-pengunjung-713516.

Hagman, Jessica, dan Janet Carleton. "Better Together: Collaborating with Students on Library Social Media." Public Services Quarterly 10, no. 3 (2014): 238-44. doi:10.1080/1522895. 2014.931207.

Haryanto. "Pemanfaatan Social Media Networks Sebagai Media Komunikasi Komunitas Pustakawan Homogen Dalam Rangka Optimalisasi Resources Sharing Knowledge Antar Perguruan Tinggi." Pustakaloka 8, No. 1 (2016).

Indonesia, Asosiasi Pengguna Jasa Internet. "APJII - Statistik Oktober 2016." Asosiasi Pengguna Jasa Internet Indonesia. Diakses 18 Januari 2017. https://apjii.or.id/survei.

Miftah, Muhammad. "Optimalisasi Kinerja Pustakawan Dalam Meningkatkan Visitasi Pemustaka." Libraria: Jurnal Perpustakaan 4, no. 2 (2016).

Phillips, Abigail L. "Facebooking It: Promoting Library Services to Young Adults through Social Media." Public Library Quarterly 34, no. 2 (3 April 2015): 178-97. doi:10.1080/01 616846.2015.1036710.

Prastowo, Andi. Manajemen Perpustakaan Sekolah Profesional. Yogyakarta: DIVA Press, 2012.

Siswanti, Apriani. "Pemanfaatan Layanan Perpanjangan Masa Peminjaman Koleksi Melalui Media Sosial Facebook di Perpustakaan Fakultas Ilmu Sosial dan Ilmu Politik Universitas Gadjah Mada Yogyakarta." Berkala Ilmu Perpustakaan dan Informasi 11, no. 2 (2015).

Varalakskhmi, R S R. "Future of Library and Information Centres in Knowledge Society of India: The Expected Role 
of Knowledge Professionals." Journal of Library and Information Technology 29, no. 2 (2009).

Webb, Hillary, dan Ken Laing. "Engaging with Social Media: The Emily Carr University of Art and Design Library Experience." Art Documentation: Bulletin of the Art Libraries Society of North America 34, no. 1 (2015): 137-51. doi:10.1086/680570.

Yan, Yalan, Xianjin Zha, Jinchao Zhang, dan Xiaorong Hou. "Comparing digital libraries with virtual communities from the perspective of e-quality." Library Hi Tech 32, no. 1 (2014): 173-89. doi:10.1108/LHT-04-2013-0042. 